kwity dłużne, pisemne ugody, asygnaty na drewno mieszczą się w tym wyobrażeniu. Do rejestrów podatkowych, zarządzeń, ordynacji (wpisywanych pro memoria do ksiąg gromadzkich) dostęp mieli (i mogli je wykorzystywać w swojej działalności) urzędnicy gromady - też chłopi - więc współgra to z tematem pracy. Natomiast omawianie znaczenia dokumentacji w kontekście zabezpieczania przed konfliktami międzyludzkimi jako świadectw aktywności religijnej i jako nośnika wiedzy o przeszłości budziło we mnie sprzeciw. Równy podział majątku w testamencie, odwołanie się w treści do Stwór$\mathrm{cy}$, wspomnienie $\mathrm{w}$ dokumencie nadania uczynionego przez władcę z dawnych czasów - jak to ma się do tej „żywej”, namacalnej dokumentacji?

Chyba że zbytnio sugeruję się tytułem pracy: Dokumentacja $w$ życiu chtopów w okresie staropolskim. Jeżeli spojrzeć jeszcze na podtytuł: Studium $z$ dziejów kultury, to może autor jednak miał prawo zająć się tymi zagadnieniami?
A może sam tytuł mógłby brzmieć nieco inaczej i nie kłaść nacisku na słowo „dokumentacja"?

We wspomnianych załącznikach do pracy autor zaprezentował zestawienia różnego rodzaju wpisów do ksiąg, które zebrał podczas kwerend. Są wśród nich np. dokonane przez chłopów obdukcje ran, protestacje, zgłoszenia grabieży, pożarów, okazania bezpańskich zwierząt gospodarczych i rzeczy znalezionych. Oprócz tego wśród załączników znajdziemy przykładowe ordynacje, zarządzenia porządkowe i wykazy obowiązków dla wybranych wsi i stanowisk urzędniczych.

$\mathrm{Na}$ koniec chciałbym wspomnieć o podsumowaniach. Stanowią one znakomite uporządkowanie treści poszczególnych rozdziałów. Autorowi należą się słowa uznania za umiejętność ich tworzenia. Punkt po punkcie wskazują najważniejsze zagadnienia z przeczytanego właśnie rozdziału. Czytałem je z prawdziwą przyjemnością.

\section{Krystian Chyrkowski}

(Uniwersytet Mikołaja Kopernika w Toruniu)

\title{
Archiwum jako projekt - poetyka i polityka (foto)archiwum, red. K. Pijar- ski, wyd. Fundacja Archeologia Fotografii, Warszawa 2011
}

Plo biór tekstów zebranych w recenzowane wydawnictwo jest szalenie interesujący. Szaleństwo to jest właściwe słowo, bo dużo rzeczy jest tutaj efemerycznych i niejasnych, wymykających się ze znanych dyskursów, już na pew- no nauki o archiwach. Nie podejmując jeszcze kwestii jakości zawartości omawianej publikacji - mnożenie perspektyw, nawet, jak się zaraz okażę, tak odległych dla klasycznej, akademickiej archiwistyki, jest już wartością samą 
w sobie. Jednocześnie, nie mam co do tego wątpliwości, jest to lektura, która winna znaleźć się w bibliotece archiwisty. Trzeba jednak zrezygnować z tej akademickiej perspektywy, by móc tę książkę docenić.

Oto w 2011 r. nakładem Fundacji Archiwum Fotografii ukazała się publikacja zrealizowana w ramach projektu FotoRejestr; projekt finansowany przez Islandię, Liechtenstein oraz Norwegię przez dofinansowanie ze środków Mechanizmu Finansowego Europejskiego Obszaru Gospodarczego oraz Norweskiego Mechanizmu Finansowego i Ministerstwo Kultury i Dziedzictwa Narodowego. Wszystkie teksty w niej zawarte prezentowane są w języku polskim i angielskim.

Książka została podzielona na sześć rozdziałów, które prezentują trzy perspektywy - spojrzenia na archiwum w kontekście postmodernistycznej Europy Środkowo-Wschodniej.

Pierwsza perspektywa zaproponowana przez redaktorów książki jest teoretyczna. Rozdział pierwszy zatytułowany $A r-$ chiwum $w$ teorii zawiera siedem tekstów uznanych badaczy oraz kuratorki z obszaru dawnego Wschodu i Zachodu Europy, którzy podjęli próbę ponownego wydobycia problemów dotyczących archiwum.

Tekst otwierający tę część nosi tytuł Maszyna archiwizacyjna - lub aparat fotograficzny i szafa kartotekowa. Autor, John Tagg, stara się przedstawić czytelnikowi zagrożenia i szanse dla humanistyki, które niesie ze sobą „zwrot archiwalny". Autor uważa, że termin archiwum przeżywa obecnie swój renesans jako narzędzie interpretacyj- ne ${ }^{1}$. Tagg stara się zachować klasyczne rozumienie terminu archiwum, sprzeciwiając się jednocześnie jego znaczeniowemu rozmyciu w czasach współczesnych (jako punkty zapalne podając wynalezienie aparatu fotograficznego i szafy kartotekowej). Równocześnie autor uważa, że rozumienie pojęcia archiwum jest kluczowe dla studiów nad historią fotografii. (Nie mylił się w tej kwestii autor. Okazuje się bowiem, że większość tekstów, które składają się na omawiane wydawnictwo próbuje przede wszystkim rozprawić się z tym pojęciem w kontekście jego natury i fenomenu jak to świadczy o samym archiwum? To pytanie należy pozostawić otwartym).

Kolejny artykuł autorstwa Wolfganga Ernsta odsłania interesującą perspektywę Tempor(e)alności fotografii. Choć jest to bardziej wykład na temat natury fotografii i jej - użyję teraz tego pojęcia intuicyjnie - tempor(e)alności to czytelnik odnajdzie tutaj fascynujące rozważania na temat „czasu, który istnieje w archiwum". I tak oto w archiwum, zdaniem autora, ,istnieją sprzeczne porządki czasowe: $\mathrm{z}$ jednej strony ma ono za zadanie zawieszać czas, aby dokonać transferu informacji dla przyszłej

1 Warto przypomnieć, że „archiwum” jako termin operacyjny, jako bodaj pierwszy wykorzystał Michael Foucault w swojej Archeologii wiedzy. Archiwum pojawiło się tam, jako jedno z najważniejszych pojęć - narzędzi w koncepcji epistemologii historii. Zob. K. O. Eliassen, The archives of Michael Foucault, [w:] The archive in Motion. New Conceptions of the Archive in Contemporary Thought and New Media Practices, red. E. Rossak, Oslo 2010, s. 32. 
pamięci (a więc działa negentropicznie), z drugiej zaś poddaje się upływowi czasu (procesom entropicznym, materialnemu rozpadowi). Trzeci aspekt zakłada wzrost szybkości dostępu, migracji i krótkotrwałych funkcji zapamiętywania, jakimi dysponuje archiwum" 2 . W artykule autor próbuje również odpowiedzieć na pytanie, które dziś sprawia największy problem w wyznaczaniu granicy dyscypliny archiwalnej w kontekście rozwoju współczesnej technologii - czy zbiory cyfrowe to wciąż są archiwa? Tę kwestię porusza również Andre Gunthert, który próbuje rozliczyć się z mitem, jakoby technologie cyfrowe zapewniały nam możliwość archiwizowania całej dokumentacji fotograficznej. W tekście Historia jako partyzantka. Dyskurs i pragmatyka archiwum fotograficznego przekonuje, że niezbędne jest dziś stworzenie „krytycznej metodologii archiwizacji fotografii".

Kwestię entropii, jako immanentną cechę archiwum, poddał pod rozwagę również Sven Spieker w kolejnym artykule zatytułowanym $O$ kwestii archiwów i entropii w sztuce wspótczesnej (Lagrady, Muntadas). Temat tekstu może wydać się na pierwszy rzut oka dziwny i przecież związany ze światem fizyki bardziej niż z tematem archiwum. Okazuje się jednak, jak udowadnia autor, że może to być niezwykle interesujące połączenie nauk. Spieker w swoim tekście

2 W. Ernst, Archiwum, przechowywanie, entropia. Tempor(e)alność fotografii, [w:] Archiwum jako projekt - poetyka i polityka (foto) archiwum, red. K. Pijarski, Fundacja Archeologia Fotografii, Warszawa 2011, s. 72. analizuje kilka prac dwóch artystów, Antoniego Mountadasa i George'a Legrady'ego, którzy przez sztukę wyrażają swój krytyczny stosunek wobec środków masowego przekazu, zajmujących się tworzeniem siatek informacji, które następnie rozpowszechniają, na różne sposoby wkraczając w pole zajmowane przez archiwa i bazy danych. $Z$ tego połącznia światów nauki i sztuki otrzymujemy niezwykłe spostrzeżenia na temat tego, czym jest i czym nie jest archiwum. Czy można zaryzykować: jest tym, czego w nim nie ma i nie jest tym, co w nim właśnie znika? Niezbędna jest lektura tekstu, w którym autor bardzo jasno i rzeczowo omawia prace wspomnianych artystów.

Kolejny artykuł zatytułowany $\mathrm{Ma}$ teria $i$ pamięć fotografii autorstwa Helen Petrovsky to próba zastanowienia się nad możliwością wpisania wspólnej pamięci bądź doświadczenia w obraz fotograficzny. Omawiając cykl prac Mikhailova Yesterday's Sandwich autorka zastanawia się, czym jest współczesne archiwum fotografii i czy w swojej definicji posiada ono miejsce na li tylko historie czy na obrazy? Kilka zdjęć Borisa Mikhailova z omawianego cyklu zostało zamieszczonych $\mathrm{w}$ wydawnictwie, co znacznie ułatwia ogląd sprawy. Również kwestię związaną z połączeniem ciało-archiwum, w podobnym zresztą kontekście jak u Muntadasa (z tym, że u niego był to komputer-archiwum) poruszyła w swoim tekście Nina Lager Vestberg, która przyjrzała się się jej przez pryzmat medium i materialności, opierając się na przykładach zaczerpniętych z powieści Antonii Susan 
Byatt Opętanie. Romans z 1990 r. oraz serialu telewizyjnego Shooting the Past Stephena Poliakoffa (1999). W tekście zatytułowanym Wskaźnik i palec. Archiwa, medium, materialność autorka próbuje nakreślić ważną rolę doświadczenia archiwalnego - medium i materialności. Vestberg chce wskazać na intymną zależność między - dosłownie - ciałem człowieka, jego palcami, a materiałami przechowywanymi w archiwum.

Ostatni tekst tej części nosi tytuł Żywe archiwum. Performatywny potencjat dokumentu. Studium przypadku: kontekstowa częśc wystawy "Promises of the Past". Autorka, Natasa Petresin-Bachelez, skupia się na tytułowej części wystawy, prezentacji powojennej sztuki Europy Wschodniej, której była współkuratorką, będącej swego rodzaju żywym archiwum odkrywającym performatywny potencjał dokumentów fotograficznych.

Drugą część wydawnictwa tworzy Perspektywa instytucjonalna. Zebrało się na nią sześć tekstów, w których archiwiści publikują swoje doświadczenia związane z tworzeniem i praktykami archiwów przechowujących materiały fotograficzne. Na szczególną uwagę czytelnika zasługują trzy spośród nich. Pierwszy, Karoliny Lewandowskiej, Miejsca organizacji pozarzadowych w obrębie dziatań archiwalnych, omawia korzyści i trudności związane z prowadzeniem instytucji pozarządowej zajmującej się przechowywaniem fotografii. Jest to praktyczny, mały przewodnik, który sugeruje sposoby działań prowadzonych przez instytucje NGO w celu zachowania płynności administracyjnej i stabilizacji finansowej. Kolejny tekst, któremu należy szcze- gólną uwagę poświęcic, a który jednak w mojej ocenie mógłby się znaleźć gdzieś między tekstami części pierwszej, to $A r-$ chiwizacja jako metafora życia, Graysona Dantzi'ego. Owszem, autor opowiada w tym krótkim tekście o tworzeniu samopomocowej, oddolnej organizacji opiekującej się archiwami swojego ojca, Jerry'ego Dantziego, czyniąc to jednak w sposób tak osobisty i intymny, że śmiało możemy mówić tutaj o obnażaniu doświadczenia archiwalnego lub osobistych przeżyć związanych z tworzeniem archiwum oraz wykonywaniem zawodu archiwisty. Wreszcie tekst trzeci, o którym chciałbym wspomnieć, to esej autorstwa Nikodema Bończa-Tomaszewskiego, który podejmuje problem związany $\mathrm{z}$ archiwami cyfrowymi i cyfrową archiwistyką, próbując wskazać wyzwania dla tego typu działań w dobie powszechnej cyfryzacji życia.

Część trzecia, jak zapewniają redaktorzy tomu, dla publikacji zasadnicza, została podzielona na cztery rozdziały. Archiwum z ukosa to swobodne dyskusje artystów z teoretykami. I tak odnajdziemy tutaj: tekst artysty Wojciecha Wilczyka oraz kulturoznawcy Iwony Kurz o fotografii dokumentalnej i archiwum; filozofki polityki, Areilli Azoulay pt. Nie ma czegoś takiego jak archiwum narodowe; rozdział Karola Radziszewskiego i Tomasza Basiuka o możliwości sformułowania alternatywnej wersji historii kultury gejowskiej w postsocjalistycznej Polsce; dyskusję między Lucią Nimcovą a Ewą Klekot o przestrzeni praktyki życia codziennego oraz pamięci ciała w Europie Środkowo-Wschodniej w czasach socjalizmu i później. 
$\mathrm{Na}$ wstępie recenzji wspomniałem o tym, że główną zaletą tej publikacji są liczne perspektywy i spojrzenia na archiwum w niej zawarte. Mam nadzieję, że tym krótkim omówieniem zawartości Archiwum jako projekt udało mi się to wykazać. Słowem podsumowania należy jeszcze powiedzieć, dlaczego publikacja ta jest nad wyraz godna uwagi czytelnika. Właściwie można by rzec, że książka ta mogłaby stać się małym kompendium wiedzy dla tych wszystkich, którzy chcą zrozumieć, czym może być poetyka archiwum, jaka gramatyka nim rządzi i dlaczego władza w archiwum może stać się miejscem oporu. Nade wszystko arcyciekawie został ujęty w pu- blikacji „zwrot archiwalny” w naukach humanistyczny (trochę celowo pomijając, jak tę kwestię rozstrzygają współczesne dyskursy historiograficzne, ale przecież nie może to być pełnoprawny zarzut, wszak w publikacji tej największą jej wartość stanowi perspektywa artystyczna). Zebranie prezentowanych tekstów w jeden tom twórczo wydobywa na powierzchnię pytania o zakres $\mathrm{i}$ istotę archiwum, o to, czym ono jest i czym mogłoby być. Pozwala także zrozumieć, jakie intelektualne bogactwo skrywa się w rozważaniach na temat archiwum i jego tożsamości, a prac o takim potencjale na polskim rynku wydawniczym wciąż próżno szukać.

Piotr Bewicz (Uniwersytet Mikołaja Kopernika w Toruniu)

\section{Zatrzymać przesztość, dogonić przyszłość. Pamiętnik VI Powszechnego Zjazdu Archiwistów Polskich, Wroctaw 5-7 września 2012 r., red. W. Cho- rążyczewski, K. Stryjkowski, Warszawa 2013}

1D) zięki tak szerokiemu hasłu przewodniemu VI Powszechnego Zjazdu Archiwistów Polskich - „Zatrzymać przeszłość, dogonić przyszłość” - zarówno samo spotkanie we Wrocławiu, jak i jego pokłosie, tj. recenzowana właśnie publikacja, to prawdziwy festiwal różnorodności, z podkreśleniem wagi wyzwań, które współczesnej archiwistyce rzuca nowoczesność. Ta właśnie cecha - różnorodność - jest w moim przekonaniu najważniejszym plusem całej publikacji. Czytelnik znajdzie tutaj teksty dotyczące bardzo szerokiego spektrum zagadnień, którymi zajmują się obecnie polscy archiwiści: komputeryzacja i digitalizacja, dokument elektroniczny, kształtowanie zasobu archiwalnego, problem zespołowości, kształcenie archiwistów w Polsce, prawo archiwalne, udostępnianie informacji archiwalnej, archiwistyka a zarządzanie dokumentacją i zarządzanie informacją, miejsce archiwum w świecie 